\section{Myxomatous degeneration of the left atrioventricular valve in a true parrot (Amazona aestiva): a case report}

\author{
Degeneração mixomatosa de valva atrioventricular esquerda \\ em papagaio verdadeiro (Amazona aestiva): relato de caso
}

\author{
Andressa Kagohara' (D), Mário dos Santos Filho² (D) José Philippe Matieli Marinho ${ }^{3}$ (D) , Daniel Marchesi Neves ${ }^{4}$ (D), \\ Luciano da Silva Alonso ${ }^{\text {(D) }}$, Jonimar Pereira Paiva ${ }^{6}$ (1) \& Daniel de Almeida Balthazar ${ }^{6 *}$ \\ 'Veterinarian. Autonomus, São Paulo, SP, Brasil \\ Veterinarian, MSc., Programa de Pós-graduação em Medicina Veterinária (PPGMV), Departamento de Medicina e Cirurgia \\ Veterinária (DCMV), Instituto de Veterinária (IV), Universidade Federal Rural do Rio de Janeiro (UFRRJ), Seropédica, RJ, Brasil \\ ${ }^{3}$ Veterinarian. Autonomus, Rio de Janeiro, RJ, Brasil \\ ${ }^{4}$ Veterinarian. Centro de Triagem de Animais Silvestres (CETAS), Seropédica, RJ, Brasil \\ ${ }^{5}$ Veterinarian, DSc. Departamento de Biologia Animal (DBA), Instituto de Ciências Biológicas e da Saúde (ICBS), UFRRJ, \\ Seropédica, RJ, Brasil \\ ${ }^{6}$ Veterinarian, DSc. DMCV, UFRRJ, Seropédica, RJ, Brasil
}

\begin{abstract}
Owning wild species as pets is becoming more and more common. Consequently, experience in caring for them has grown, resulting in the diagnosis of numerous diseases. Among these are cardiovascular disorders, especially in parrots. However, the lack of specificity or the absence of clinical signs of these diseases make it difficult to assess cardiovascular issues during the physical examination of birds. This leads to underdiagnosis of these conditions, with the majority being diagnosed post-mortem. This study reports the cardiovascular findings in post-mortem examinations of individuals of the species Amazona aestiva (true parrot) of Centro de Triagem de Animais Silvestres do Rio de Janeiro (CETAS-RJ) and is the first record of myxomatous degeneration of the left atrioventricular valve in this species.
\end{abstract}

Keywords: psittacine, endocardiosis, congesti've heart failure.

\section{Resumo}

A criação de espécies silvestres como animais de estimação vem aumentando e ganhando espaço na vida familiar e, como consequência, os cuidados com os mesmos aumentaram, permitindo o diagnóstico de inúmeras enfermidades. Dentre elas, estão as doenças cardiovasculares, em especial nos psitaciformes. Entretanto, a inespecificidade ou mesmo a ausência de sinais clínicos associados à dificuldade da avaliação do sistema cardiovascular no exame físico das aves faz com que tais alterações sejam subdiagnosticadas na rotina clínica, sendo a maioria dos casos diagnosticados post mortem. O presente trabalho relata as alterações cardiovasculares reveladas em exame post mortem em indivíduos da espécie Amazona aestiva (papagaio verdadeiro) provenientes do Centro de Triagem de Animais Silvestres do Rio de Janeiro (CETAS-RJ) e faz o primeiro registro de degeneração mixomatosa da valva atrioventricular esquerda nesta espécie.

Palavras-chave: psitacídeos, endocardiose, insuficiência cardíaca congestiva.

\section{Introduction}

Owning wild species as pets is becoming more common in society at large. Consequently, demand has increased for veterinarians to have knowledge of the nosological profiles of these animals. Among these unconventional pets, birds are prominent, particularly those belonging to the order Psittaciformes. Bringing these animals into the family environment, increasing their routine care by specialized veterinarians, has led to the diagnosis of various diseases including cardiovascular conditions (Pees et al., 2006).

In birds, the heart is located in the upper part of the coelomic cavity and has the peculiarity of having a base larger than its apex, due to the confluence of the large cardiac vessels. It has two atrial and two ventricular chambers, with the left ventricular chamber elongated to form the distal portion of the cardiac apex. Separating the cardiac chambers are the left and right atrioventricular valves, formed by the endocardial portion. Moreover, there are the semilunar, \section{B] M \\ Brazilian Journal of Veterinary Medicine \\ p-ISSN 0100-2430 \\ e-ISSN 2527-2179 \\ ○}

How to cite: Kagohara, A., Santos Filho, M., Marinho, J. P. M., Neves, D. M., Alonso, L. S., Paiva, J. P., \& Balthazar, D. A. (2020). Myxomatous degeneration of the left atrioventricular valve in a true parrot (Amazona aestiva): a case report. Brazilian Journal of Veterinary Medicine, 42. e104720. https://doi.org/10.29374/2527-2179. bjvm104720

\section{Financial support: None}

Conflict of interests: No conflict of interests declared concerning the publication of this article.

Received: March 29, 2019.

Accepted: April 24, 2020.

The study was carried out at Laboratório de Anatomia Animal, Universidade Federal Rural do Rio de Janeiro - UFRRJ, Seropédica, RJ, Brasil.

\section{*Correspondence}

Daniel de Almeida Balthazar

Departamento de Medicina e Cirurgia Veterinária, Universidade Federal Rural do Rio de Janeiro - UFRRJ

Bairro Zona Rural, Campus Seropédica CEP 23851-790 - Seropédica (RJ), Brasil

E-mail: danielbalthazar@yahoo.com.br

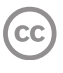

Copyright Kagohara et al. This is an Open Access article distributed under the terms of the Creative Commons Attribution License, which permits unrestricted use, distribution, and reproduction in any medium, provided the original work is properly cited. 
pulmonary, and aortic valves, which prevent blood reflux from the exit of the pulmonary and aortic arteries (Guimarães et al., 2018).

In recent years, some cardiovascular diseases have been reported in parrots, for example, atherosclerosis and valvular disease that lead to congestive heart failure (CHF) (Rosenthal \& Stamoulis, 1993; Oglesbee \& Lehmkuhl, 2001; Krautwald-Junghanns et al., 2004; Pees et al., 2006). This can be explained in part by inadequate care for parrots, as pets are often raised with space and exercise restrictions. These promote stress, along with inadequate diets with a high lipid content (too many seeds), predisposing the animals to obesity and other metabolic disorders (Krautwald-Junghanns et al., 2004). In addition, the cardiovascular system of these animals was developed to support high physical performance, responding to physiological demands of increased heart rate, blood pressure, and cardiac output (Lumeji \& Ritchie, 1994).

Changes due to endocardiosis promote valve failure that can lead to the development of CHF (Oglesbee \& Lehmkuhl, 2001). The leaflets lose their normal shape and fail to close completely, generating an atrioventricular reflux that overloads the left side of the heart. As an aggravating factor in the development and decompensation of left-sided CHF, passive lung congestion may also occur, which increases pulmonary pressure, leading to hypertension. This, in turn, overloads the right side of the heart, culminating in right-sided CHF (Oglesbee \& Lehmkuhl, 2001).

The clinical signs that can be seen in animals with CHF include cyanosis of the periorbital region, exercise intolerance, abdominal distension, dyspnea, and sudden death (Pees \& KrautwaldJunghanns, 2009). However, the lack of specificity or even the absence of these clinical signs, combined with difficulties in assessing the cardiovascular system upon physical examination, results in these diseases being underdiagnosed. As a result, most cases are diagnosed postmortem (Pees \& Krautwald-Junghanns, 2009). Early diagnosis, as well as adequate monitoring, is essential to delay the development of CHF and to improve the patient's quality of life and well-being (Pees et al., 2006).

This paper reports the heart valve changes revealed in a post-mortem examination in Amazona aestiva, donated by CETAS-RJ, and is the first record of myxomatous degeneration of the left atrioventricular valve in this species.

\section{History}

Post-mortem examinations were carried out in nine animals of the species Amazona aestiva (true parrot). The dead animals were donated by Centro de Triagem de Animais Selvagens do Rio de Janeiro (CETAS-RJ), from previously captured birds. These animals had been kept in a screened enclosure with other animals of the same species, and fed with a mixture of seeds and chopped fresh fruits. After some time, they began to die gradually, without a definite cause. Eventually, eighty frozen cadavers were donated to the anatomy laboratory of the Universidade Federal Rural do Rio de Janeiro. These were kept frozen for a period of 1 to 4 weeks. From these, nine individuals were chosen at random. The post-mortem examination was conducted as described by Latimer \& Rakich (1994).

On external inspection, all the cadavers had a low body condition score, evaluated according to the filling of the pectoral muscles in relation to the carina. Scoring was from 1 to 5 , as follows: 1 , no or almost no filling evident in the muscles, and obvious carina; 2 , slight muscular filling and evident carina; 3, normal muscular filling, visible carina; 4, good muscular filling and slightly evident carina; 5, good muscular filling and non-evident carina. In addition, the animals showed changes in the color of their feathers, tending to yellow, and no other physical changes of note.

After the inspection, the coelomic cavities of the nine individuals were fully opened, and the findings were as follows:

Individual I): high parasitic infestation, hepatomegaly with a dark red color with the presence of blood at the cut site, and ascites;

Individual II): cardiomegaly, nodules in the left AV valve (Figure1), pericardial effusion, engorged appearance, a dark red color with the presence of blood at the cut site, hepatomegaly with dark red color with blood at the cut site, and ascites;

Individual III): cardiomegaly, discolored and hardened lungs, hepatomegaly with a dark red color and the presence of blood at the cut site, and ascites: 


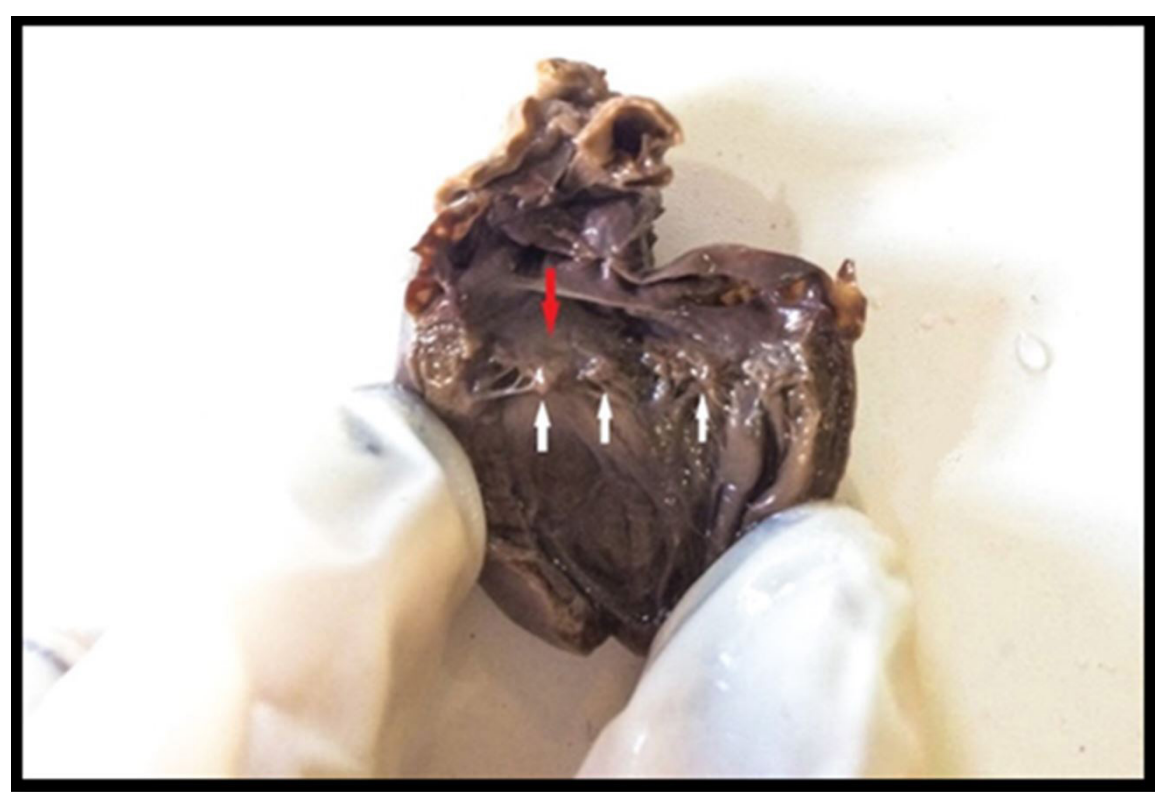

Figure 1. Longitudinal section of a heart, showing the left atrioventricular valve, the presence of nodules (white arrows), and increased opacity and thickening (red arrow).

Individual IV): cardiomegaly, discolored and hardened left AV valve nodules, and a dark red coloration with blood at the cut site;

Individual V): discolored, with a stiff appearance, high parasitic infestation, and hepatomegaly with a dark red color and the presence of blood at the cut site;

Individual VI): cardiomegaly, nodules and thickening in the left AV valve, pericardial effusion, engorged appearance, a dark red color with the presence of blood at the cut site, and hepatomegaly with a dark red color and the presence of blood at the cut site;

Individual VII): cardiomegaly, nodules and thickening in the left AV valve, pericardial effusion, engorged appearance, a dark red color and with the presence of blood at the cut site, and hepatomegaly with a dark red color and the presence of blood at the cut site;

Individual VIII): cardiomegaly, nodules in the left AV valve, pericardial effusion, engorged appearance, a dark red color and with the presence of blood at the cut site, and hepatomegaly with dark red color and the presence of blood at the cut site;

Individual IX): discolored and stiff.

Due to the findings in the mitral valves, the hearts of individuals II, IV, VI, VII, and VIII were selected for histopathological analysis. This revealed mild deposition of myxoid tissue in the left $\mathrm{AV}$ valve in the five analyzed hearts (Figure 2), and in three of them, collagen deposition was also observed (Figure 3).

\section{Discussion}

The weight loss present in the examined corpses is a non-specific sign, found in chronic conditions that affect birds, because of a hypermetabolic state that promotes muscle catabolism (Doneley, 2010). This is likely due to the stressful living conditions of the studied individuals, as a result of their capture and adaptation to a new environment, in addition to parasitic infestation that was evident in two of the individuals. The change in the color of the feathers is also a non-specific sign that can be indicative of conditions such as liver disease and nutritional deficiencies (Doneley, 2010), which can also be correlated with their history of stress, poor health, and poor diet management.

In the lungs, the most frequent changes observed were the engorged appearance, dark red color, and the presence of blood at the cut site, which are signs that indicate pulmonary congestion (Oglesbee \& Lehmkuhl, 2001). This was a passive event, secondary to the accumulation of blood 


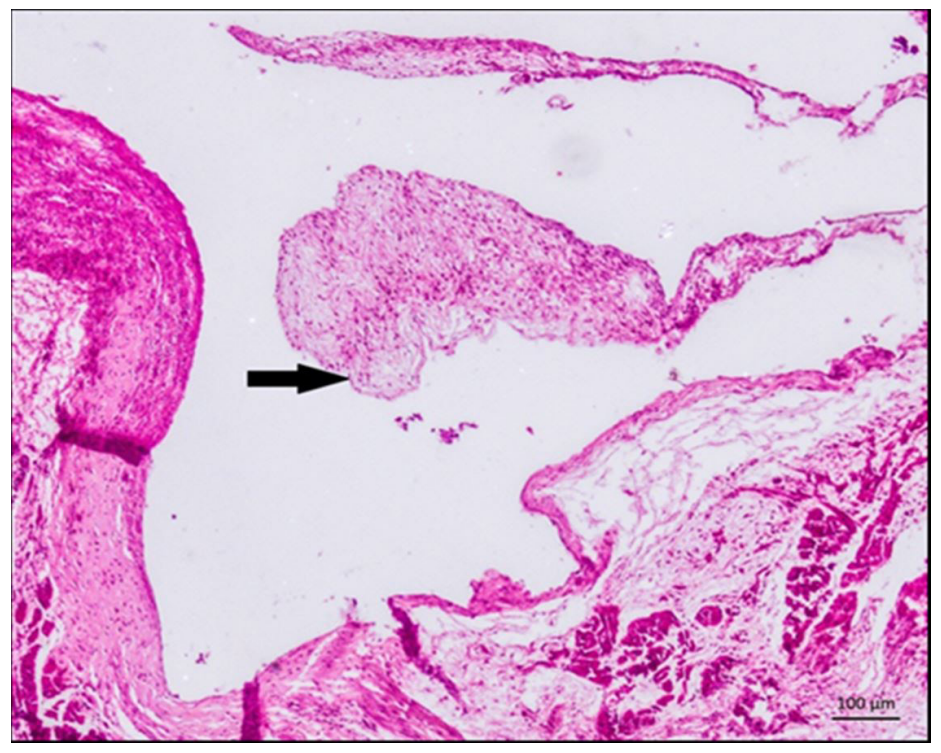

Figure 2. Histological section of the left atrioventricular valve with accumulation of myxoid tissue (arrowhead). $(\mathrm{H} \& \mathrm{E}, \times 25)$.

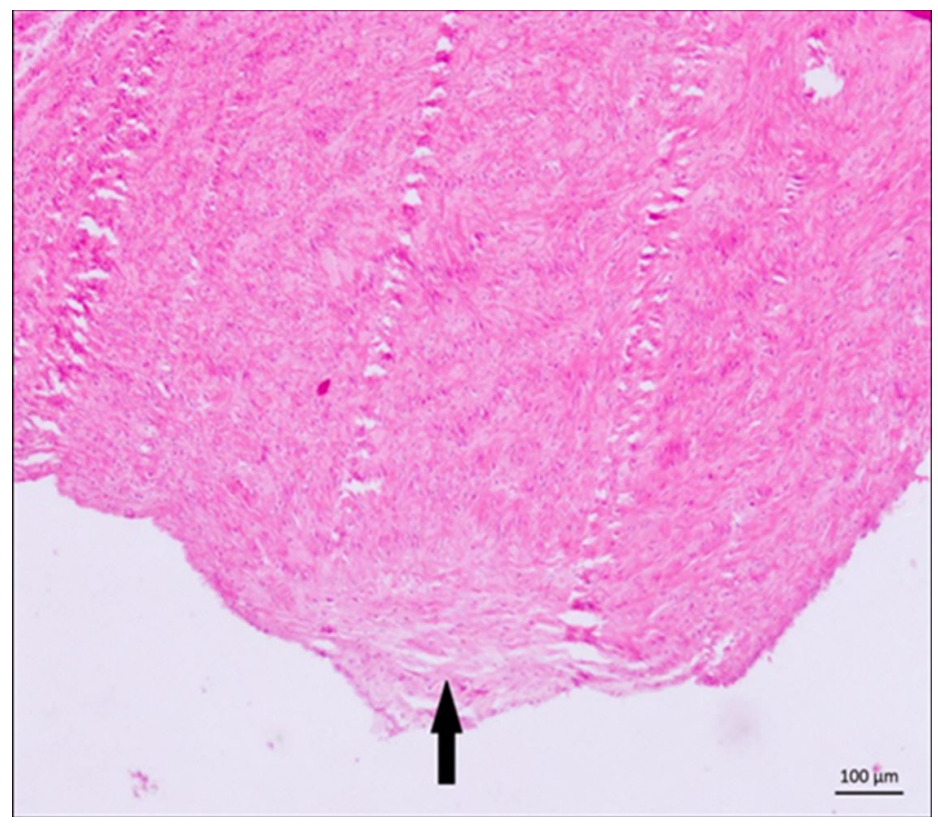

Figure 3. Histological section of the left atrioventricular valve showing collagen deposition (arrowhead). (H\&E, ×25).

in the pulmonary veins, occurring due to left atrioventricular reflux and decreased cardiac output. Untreated pulmonary congestion can lead to overloading of the right side of the heart, which is sensitive to increased pressure in the pulmonary vessels. This is due to the relative thinness of the right ventricular wall and the anatomy of the atrioventricular valve, which changes along with the myocardium, increasing in size and promoting atrioventricular reflux (Oglesbee \& Lehmkuhl, 2001).

In addition to congestion, in some individuals, the lungs were found to be stiff and discolored. This type of change is generically described as pulmonary consolidation, caused by chronic pulmonary disorders such as pneumonia (Hopkins \& Olson, 1999).

The liver presented several changes: a dark red color, an increase in parenchymal size, and the presence of blood at the cut site, which are signs typical of animals with hepatic congestion (Oglesbee \& Lehmkuhl, 2001). Hepatic congestion is a common finding in animals that develop 
right-sided heart failure (Kaya et al., 2015), which slows venous return, leading to the accumulation of blood in systemic vessels and organs, especially in the liver. This can lead to leakage of cavity fluid (Krautwald-Junghanns et al., 2004), which may explain the presence of ascites in some individuals, since they also had cardiomegaly. Other changes observed in the macroscopic examination of the livers were firm consistency, notable pallor, and reduced size, which are findings indicative of liver atrophy or cirrhosis (Schmidt et al., 2003).

The hydropericardium, which was observed in three animals, may have had etiologies other than cardiogenic (Lumeji \& Ritchie, 1994). In the light of the other findings, it was attributed to CHF since the animals presented with concomitantly dilated cardiac chambers (Kaya et al., 2015).

The presence of nodules on the left atrioventricular valve has been described in birds and is generally ascribed to chronic degenerative mitral valve disease or endocardiosis (Lumeji \& Ritchie, 1994). However, there is another process that can trigger nodular formation and valve degeneration: endocarditis (Oglesbee \& Lehmkuhl, 2001). This is characterized by the formation of bacterial plaques and fibrosis, which can lead to congestive heart failure. However, it is possible to observe signs of infection in other organs, due to bacterial translocation. In addition to being present upon histopathological examination, endocarditis is characterized by the presence of bacterial proliferation, mixed inflammatory infiltrate with different defense cells, and collagen deposition (Lemon et al., 2012).

Cardiovascular diseases in birds are associated with conditions of improper management of these animals in captivity, along with high-calorie diets (restricted to seeds), absence of exercise, and inadequate confinement spaces, which are conditions that predispose most heart diseases (Wit \& Schoemaker, 2005; Pees et al., 2006).

The histopathological findings of the left atrioventricular valves of the five hearts sent for analysis revealed depositions of myxoid tissue and, in three of them, thickening due to collagen deposition. These findings, together with the macroscopic lesions observed, have been described by Schmidt et al. (2003), as myxomatous degeneration or atrioventricular valve endocardiosis. We can state with certainty that the lesions present in the valves were not secondary to bacterial endocarditis, given the absence of the histopathological characteristics mentioned earlier.

Endocardiosis is not frequently reported in birds, presenting in isolated cases in some species (Rosenthal \& Stamoulis, 1993; Oglesbee \& Lehmkuhl, 2001; Strunk \& Wilson, 2003). This is the first report of myxomatous degeneration of the left atrioventricular valve in Amazona aestiva.

\section{Conclusion}

By correlating the history of these animals with their necroscopic findings, we have shown that the inadequate management of these species in captivity predisposed them to valve degeneration. This information points to the importance of careful attention to diet, management, and confinement conditions, when caring for this species and when breeding them in captivity.

\section{References}

Doneley, B. (2010). Differential diagnoses. In B. Doneley, Avian medicine and surgery in practice (p. 97). London: Manson Publishing. http://dx.doi.org/10.1201/b15176-7.

Guimarães, D. F., Carvalho, A. P. M., Ywasaki, Y., Neves, C. D., Rodrigues, A. B. F., \& Silveira, L. S. (2018). Morfologia do coração e dos vasos da base do pinguim-de-magalhães (Spheniscus magellanicus). Arquivo Brasileiro de Medicina Veterinária e Zootecnia, 70(4), 1195-1202. http://dx.doi.org/10.1590/1678-4162-9860.

Hopkins, B. A., \& Olson, L. D. (1999). Increased left lung consolidation in turkey cholera releated to larger left pulmonary artery. Avian Diseases, 43(1), 122-124. http://dx.doi.org/10.2307/1592770. PMid:10216768.

Kaya, M., Gacar, A., Demirci, B., Soylu, S. M., \& Gulbahar, M. Y. (2015). Atrioventricular dissociation and congestive heart failure in a Ring-necked Pheasant (Phasianus colchicus). Journal of Avian Medicine and Surgery, 29(2), 136-141. http://dx.doi.org/10.1647/2013-064. PMid:26115214.

Krautwald-Junghanns, M. E., Braun, S., Pees, M., Straub, J., \& Valerius, H.-P. (2004). Research on the anatomy and pathology of the psittacine birds. Journal of Avian Medicine and Surgery, 18(1), 2-11. http://dx.doi. org/10.1647/2002-004

Latimer, K. S., \& Rakich, M. P. (1994). Necropsy examination. In W. B. Ritchie, J. G. Harrison \& R. L. Harrison (Eds.), Avian medicine: principles and application (pp. 356-376). Lake Worth, Florida: Wingers Publishing.

Lemon, M. J., Pack, L., \& Forzán, J. M. (2012). Valvular endocarditis and septa thrombosis associated with a radial fratture in a red-tailed hawk (Buteojamaicensis). The Canadian Veterinary Journal. La Revue Veterinaire Canadienne, 53(1), 79-82. PMid:22753969. 
Lumeji, T. J., \& Ritchie, W. B. (1994). Cardiology. In W. B. Ritchie, J. G. Harrison \& R. L. Harrison (Eds.), Avian medicine: principles and application (pp. 695-696). Lake Worth, Florida: Wingers Publishing.

Oglesbee, B. L., \& Lehmkuhl, L. (2001). Congestive heart failure associated with myxomatous degenerative of the atrioventricular valve in parakeet. Journal of the American Veterinary Medical Association, 218(3), 376-380, 360. http://dx.doi.org/10.2460/javma.2001.218.376. PMid:11201563.

Pees, M., \& Krautwald-Junghanns, M. E. (2009). Cardiovascular physiology and diseases of pet birds. The Veterinary Clinics Exotic Pet Medicine, 12(1), 81-97, vi. http://dx.doi.org/10.1016/j.cvex.2008.08.003. PMid:19131032.

Pees, M., Schmidt, V., Coles, B., \& Krautwald-Junghanns, M.-E. (2006). Short communications: diagnosis and long term therapy of right sided heart failure in a yellow crowned amazon (Amazona ochrocephala). The Veterinary Record, 158(1), 445-447. http://dx.doi.org/10.1136/vr.158.13.445. PMid:16581996.

Rosenthal, K., \& Stamoulis, M. (1993). Diagnosis of congestive heart failure in a Indian Hill Mynah Bird (Gracula religiosa). Journal of the Association of Avian Veterinary, 7(1), 101-106. http://dx.doi.org/10.2307/30134305.

Schmidt, R. E., Reavill, D. R., \& Phalen, D. N. (2003). Liver. In R. E. Schmidt, D. R. Reavill \& D. N. Phalen (Eds.) Pathology of caged and aviary birds (pp. 67-80). Iowa: Blackwell Publishing.

Strunk, A., \& Wilson, G. H. (2003). Avian Cardiology. The Veterinary Clinics of North America. Exotic Animal Practice, 6(1), 1-28, v. http://dx.doi.org/10.1016/S1094-9194(02)00031-2. PMid:12616832.

Wit, M., \& Schoemaker, N. J. (2005). Clinical approach to avian cardiac disease. Seminars in Avian and Exotic Pet Medicine, 14(1), 6-13. http://dx.doi.org/10.1053/j.saep.2005.12.004. 